\title{
Downy Mildew of Lettuce in Florida ${ }^{1}$
}

\author{
Lis Rodrigues-Porto, Richard N. Raid, and Germán V. Sandoya²
}

\section{The Importance of Lettuce and Impact of Downy Mildew in Florida}

The United States produces $15 \%$ of the world's lettuce (Table 1), and Florida ranks third among states, following only California and Arizona (Figure 1). In Florida, lettuce is mostly field grown, with limited production in protected structures. The majority of Florida's field production is located on the rich organic "muck" soils of the Everglades Agricultural Area (EAA), amounting to over 10,000 acres, primarily in Palm Beach County. The state's production values for the lettuce crop routinely exceed $\$ 80$ million annually. In response to a growing demand for organically produced lettuce, production within protected structures (greenhouses) has expanded in recent years. Such facilities offer a distinct advantage in terms of greater environmental control. A recent survey conducted and compiled with responses from 240 grower operations in Florida indicated rapid growth in this type of production within the state of Florida.

Lettuce downy mildew (LDM) is the most important disease of lettuce worldwide, with losses of up to $100 \%$ reported in individual fields in Florida. Primarily a foliar disease, LDM has a direct effect on both yield and quality of lettuce. Although direct yield losses in the field at harvest may be substantial, LDM's impact is often accentuated by significant postharvest losses that occur during transportation or storage. In addition to the postharvest losses, LDM lesions may facilitate infections by other pathogens, such as the fungus Botrytis cinerea, or they may enhance opportunities for foodborne pathogens, such as Escherichia coli or Salmonella enterica.

Lettuce Production in the United States in 2017

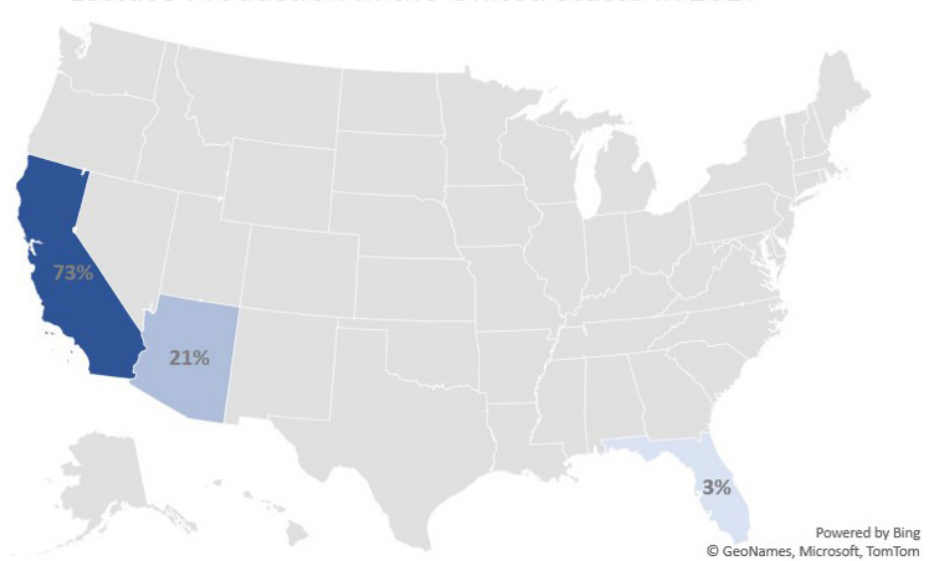

Figure 1. Percentage based on production of lettuce planted in California, Arizona, and Florida in the United States according to the USDA Census of Agriculture in 2017. Source: https://www.nass.usda. gov/

Credits: Lis Natali Rodrigues Porto, UF/IFAS

\section{Causal Organism}

LDM is caused by the oomycete Bremia lactucae Regel. Oomycetes were previously considered part of the Fungi kingdom; however, molecular and phylogenetic techniques now classify oomycetes into the Chromista kingdom, more closely related to algae and green plants. B. lactucae is an obligate parasite, which means that this oomycete is only capable of infecting and colonizing living lettuce tissue. The pathogen is genetically diverse and is distributed worldwide.

1. This document is HS1403, one of a series of the Horticultural Sciences Department, UF/IFAS Extension. Original publication date January 2021. Visit the EDIS website at https://edis.ifas.ufl.edu for the currently supported version of this publication.

2. Lis Rodrigues-Porto, graduate student, Horticultural Sciences Department; Richard N. Raid, professor, Plant Pathology Department; and Germán V. Sandoya, assistant professor, Horticultural Sciences Department; UF/IFAS Everglades Research and Education Center, Belle Glade, FL 33430.

The Institute of Food and Agricultural Sciences (IFAS) is an Equal Opportunity Institution authorized to provide research, educational information and other services

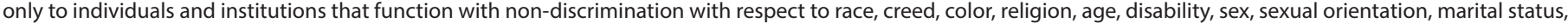

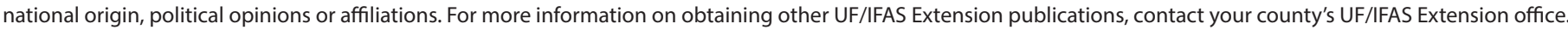
U.S. Department of Agriculture, UF/IFAS Extension Service, University of Florida, IFAS, Florida A \& M University Cooperative Extension Program, and Boards of County Commissioners Cooperating. Nick T. Place, dean for UF/IFAS Extension. 
Due to the importance of the disease, an International Bremia Evaluation Board (IBEB) was created in 1999 (https://www.worldseed.org/our-work/plant-health/ other-initiatives/ibeb/) with the objective to identify and designate new races of $B$. lactucae. The IBEB currently has two chapters, one in the United States and the other in Europe, and it is expected that other lettuce-production areas will create additional chapters in the future. Ten races of $B$. lactucae have been described in the western United States and 15 races in Europe. LDM is widespread in the United States, but race classification remains unknown in Florida.

In the United States and Europe, the identification of races of the LDM pathogen is established upon the use of a set of 15 lettuce accessions designated as differentials (Table 2). These accessions' reactions are race specific. Therefore, host response is used to classify $B$. lactucae races. Information on race characterization is expanding in the Western Hemisphere, with three new races of the pathogen recently identified in Brazil. However, B. lactucae classification in other regions of the world remains scarce. In northern Asia, LDM has been identified in 19 different countries at high populations, but at present, race classification remains unknown.

\section{Symptoms}

B. lactucae may infect lettuce at any growth stage, from seedling to mature plant. Commercial crisphead, leaf, and cos lettuce types are all susceptible; however, wild types of the genus Lactuca are generally more resistant. Symptoms of LDM appear initially as chlorotic yellow spots on the underside of the leaf surface. Under favorable conditions, a white, cotton-like growth that is indicative of the formation of sporangia (sporulation) generally appears on the lower leaf surface within 24 to 48 hours following initial symptom development (Figure 2A). During early stages of disease development, lesions are often delineated by leaf veins, giving infections a rather angular appearance (Figures 2B and $2 \mathrm{C}$ ). As the disease progresses, lesions coalesce, and only larger veins obstruct lesion expansion. Lesions become increasingly chlorotic over time and eventually turn brown (Figure 2D) and necrotic. Although LDM is usually most severe on mature outer leaves, the disease may become systemic, infecting lettuce heads internally and even roots.

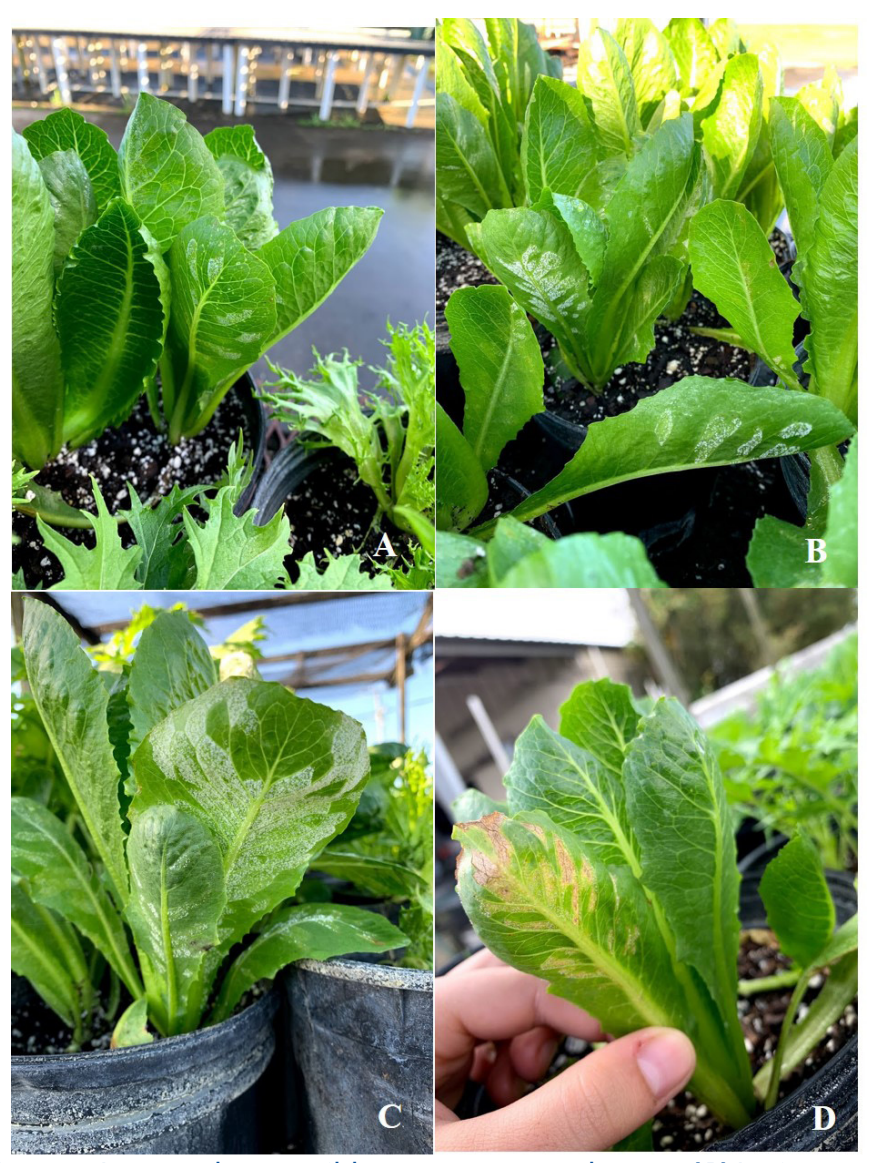

Figure 2. Lettuce downy mildew symptoms on lettuce. (A) Lesions exhibiting an angular appearance on the lower leaf surface. (B) Lesions delineated by the veins of the leaf beginning to coalesce. (C) Profuse cotton-like growth indicative of sporulation on the lower leaf surface. (D) Leaf necrosis resulting from lesion coalescence and maturation.

Credits: Lis Natali Rodrigues Porto, UF/IFAS

\section{Disease Cycle/Epidemiology}

B. lactucae is spread by the formation and dissemination of tiny spores called sporangia. The sporangia are borne on small, treelike structures (sporangiophores) that emerge through stomata in the leaf surface. Clusters of these treelike structures can be observed without magnification as a white, cotton-like growth on the lower leaf surface of mildew lesions. Spores are normally formed at night and are released during the day when the relative humidity is somewhat lower. Sporangia may then be either rainsplashed or wind-disseminated to healthy host tissue, each capable of inciting new infections. Although rain-splash dissemination normally ranges from several inches to several feet, sporangia may be windblown tens to hundreds of miles and remain viable for infection. Spores of $B$. lactucae may infect, colonize, and produce a second generation of spores in as few as 5 to 7 days. With the potential for tens of thousands of sporangia to be formed on the underside of each lesion under favorable conditions, LDM is capable of spreading rapidly over large areas. Sporulation 
and infection by $B$. lactucae are both favored by relatively cool temperatures and humid or moist environmental conditions. For this reason, epidemics in south Florida usually occur between December and March, when nighttime temperatures frequently drop to $40^{\circ} \mathrm{F}$ to $60^{\circ} \mathrm{F}$. Five to seven hours of high humidity (near $100 \% \mathrm{RH}$ ) or leaf wetness are also required for successful infection and sporulation.

In addition to sporangia, thick-walled sexual spores, called oospores, are also formed by B. lactucae. Oospores may enable the pathogen to survive in the absence of a suitable host, thus serving as initial inoculum for subsequent epidemics.

\section{Management Options}

LDM is difficult to manage in field operations due to its rapid growth and extensive dissemination. Therefore, a well-designed integrated LDM management plan that includes host resistance, the use of chemicals, and any cultural practices is strongly encouraged.

\section{Host Resistance}

Cultivar resistance, when available, is the best form of LDM control. Many lettuce cultivars are resistant to different races of LDM; these resistances may be complete or partial. Resistance in lettuce is conferred by one or a few genes $(\mathrm{Dm}$ Downy mildew). At least 20 single dominant genes for resistance to $B$. lactucae have already been identified to protect against different LDM races, facilitating the introduction of resistance into breeding programs. Unfortunately, the resistance of lettuce against LDM is not durable due to the variability within the pathogen population and the rapid evolution of different and newer races.

The UF/IFAS Lettuce Breeding Program was created to release lettuce cultivars adapted to Florida conditions. The program's effort is to identify races of LDM in Florida to breed lettuce resistant to the disease. During the winter of 2017, commercial lettuce cultivars and breeding lines from UF/IFAS were assessed in the field for LDM symptoms by natural infestation. Most commercial lettuce cultivars currently planted at the EAA are susceptible to B. lactucae, but high levels of resistance in the UF/IFAS lettuce breeding germplasm do exist and are being incorporated into Florida's adapted germplasm (Table 3).

\section{Cultural Practices}

Establishment of a lettuce-free period, crop rotation, and rapid destruction of infected crop residues are recommended cultural control measures to reduce LDM in
Florida lettuce. Field-grown lettuce is a seasonal crop in Florida, and the lettuce-free period is from April/May to September/October. If the crop is planted in protected structures, growers are still encouraged to establish a lettuce-free period to avoid the disease becoming an issue. Because LDM is a specific disease of lettuce, the adoption of crop rotation with nonhost crops will help to interrupt the disease cycle by eliminating the presence of its host.

The incorporation of infected crop residues into the soil immediately after harvest may also help to slow down the spread of the disease to other areas. Because moisture or high humidity is required for infection and sporulation, irrigation practices, such as drip irrigation, that minimize leaf wetness or soil moisture should also be utilized. However, drip irrigation is not currently used in Florida's lettuce production systems.

Given the current susceptibility of most commercial lettuce cultivars grown in Florida, LDM is extremely difficult, if not impossible, to maintain at noneconomic levels once a major outbreak has occurred. For this reason, prevention and early detection are of the utmost importance. Because of LDM's ability to spread over long distances and large areas in a short period of time, lettuce producers are urged to communicate freely with each other, UF/IFAS Extension personnel, and consultants in the area. Early notification that downy mildew is in the vicinity is a tremendous help in minimizing control costs and limiting area-wide outbreaks and losses.

\section{Chemical Control}

The Vegetable Production Handbook of Florida (https:// edis.ifas.ufl.edu/cv293) has an extensive list of chemicals labelled for LDM for field operations. These include several broad-spectrum protectants, such as sulfur, copper fungicides, and mancozeb, as well as an assortment of more specific oomycete compounds, many of which are translaminar or systemic. For other type of operations, including organic production or lettuce produced in protected structures, stakeholders should verify the respective label approval. Contact your UF/IFAS Extension agent for current recommendations and inspect the label of approved products for the required personal protection equipment (PPE).

To optimize efficacy, it is suggested that prophylactic chemical applications be initiated when favorable conditions for pathogen infection occur (i.e., when night temperatures dip into the $40^{\circ} \mathrm{F}$ to $60^{\circ} \mathrm{F}$ range and there are at least five to seven hours of high humidity). It is preferable 
that fungicides be in place before infection occurs so that control is maximized. If it is already known that LDM is present in the area, it is recommended that a comprehensive fungicide program start as soon as possible to avoid severe losses.

\section{References}

CABI. 2020. "Bremia lactucae (Downy Mildew of Lettuce)." Invasive Species Compendium. Wallingford, UK: CAB International. https://www.cabi.org/isc/datasheet/9937

Castoldi, R., H. C. O. Charlo, T. Dalpian, D. M. Melo, A. P. Botelho, and L. T. Braz. 2012. "Identification of New Bremia lactucae Races in Lettuce in São Paulo State." Horticultura Brasileira 30 (2): 209-213. https://doi.org/10.1590/ S0102-05362012000200005

Channon, A. G., and Y. Smith. 1970. "Further Studies on Races of Bremia lactucae Regel." Horticultural Research 10:14-19.

Crute, I. R. 1992. "From Breeding to Cloning (and Back Again?): A Case Study with Lettuce Downy Mildew." Annu. Rev. Phytopathol. 30:485-506.

Datnoff, L. E., R. T. Nagata, and R. N. Raid. 1994. "Pathotyping of Bremia lactucae in Florida." Plant Disease 78:854-857.

Food and Agriculture Organization of the United Nations (FAO). 2020. “FAOSTAT.” https://www.fao.org/faostat/en/

Hochmuth, G. J., R. C. Hochmuth, W. D. Thomas, and M. S. Sweat. 2001. Crop Production-Florida Greenhouse Vegetable Production Handbook, Vol 1. HS769. Gainesville: University of Florida Institute of Food and Agricultural Sciences. https://edis.ifas.ufl.edu/cv247

International Bremia Evaluation Board (IBEB). 2020. "Bremia lactucae." https://www.worldseed.org/our-work/ plant-health/other-initiatives/ibeb/

Kanissery, R., R. N. Raid, J. Desaeger, J. Beuzelin, and C. F. Miller. 2020. Chapter 9. Leafy Vegetable Production. In The Vegetable Production Handbook of Florida, 2020-2021 edition. HS728. Gainesville: University of Florida Institute of Food and Agricultural Sciences. https://edis.ifas.ufl.edu/ cv293

Lebeda, A., I. Doležalová, and E. Kř́ístková. 2007. "Lettuce (Asteraceae; Lactuca spp.).” In Genetic Resources, Chromosome Engineering, and Crop Improvement: Vegetable Crops,
Volume 3, edited by R. J. Singh, 377-472. Boca Raton, FL: CRC Press.

Marin, M. V., C. A. Franco, D. Smilde, R. C. Panizzi, and L. T. Braz. 2020. "Distribution of Races and Virulence Factors of Bremia lactucae in the Main Lettuce Production Area in Brazil." J Plant Pathol 102:395-407. https://doi.org/10.1007/ s42161-019-00444-X

Michelmore, R., O. Ochoa, and J. Wong. 2009. “Bremia lactucae and Lettuce Downy Mildew." In Oomycete Genetics and Genomics: Diversity, Interactions, and Research Tools, edited by K. Lamour and S. Kamoun, 241-262. Hoboken: John Wiley \& Sons, Inc.

Parra, L., B. Maisonneuve, A. Lebeda, J. Schut, M. Christopoulou, M. Jeuken, L. McHale, M. J. Truco, I. Crute, and R. Michelmore. 2016. "Rationalization of Genes for Resistance to Bremia lactucae in Lettuce." Euphytica 210:309-326. https://doi.org/10.1007/s10681-016-1687-1

Reddy, P. P. 2016. Sustainable Crop Protection under Protected Cultivation. Singapore: Springer. p. 328. https://doi. org/10.1007/978-981-287-952-3

Scherm, H., and A. H. C. van Bruggen. 1995. "Concurrent Spore Release and Infection of Lettuce by Bremia lactucae during Mornings with Prolonged Leaf Wetness." American Phytopathological Society 85 (5): 552-555. https://doi. org/10.1094/Phyto-85-552

Simko, I., Y. Zhou, and M. T. Brandl. 2015. "Downy Mildew Disease Promotes the Colonization of Romaine Lettuce by Escherichia coli O157:H7 and Salmonella enterica." BMC Microbiol 15:19. https://doi.org/10.1186/s12866-015-0360-5

Spring, O., J. Gomez-Zeledon, D. Hadziabdic, R. N. Trigiano, M. Thines, and A. Lebeda. 2018. "Biological Characteristics and Assessment of Virulence Diversity in Pathosystems of Economically Important Biotrophic Oomycetes." Critical Reviews in Plant Sciences 37 (6): 439-495. https://doi.org/10.1080/07352689.2018.1530848

United States Department of Agriculture (USDA). 2020. “Vegetables 2019 Summary." USDA, National Agricultural Statistics Service.

van Treuren, R., A. J. M. van der Arend, and J. W. Schut. 2013. "Distribution of Downy Mildew (Bremia lactucae Regel) Resistances in a Genebank Collection of Lettuce and Its Wild Relatives." Plant Genetic Resources 11 (1): 15-25. https://doi.org/10.1017/S1479262111000761 
Table 1. The top ten lettuce-producing countries in 2018 in terms of harvested area, yield, and production according to the FAO. Source: http://www.fao.org/faostat/en/\#home

\begin{tabular}{|l|c|c|c|}
\hline \multicolumn{1}{|c|}{ Country } & Harvested area (acres) ${ }^{1}$ & Yield (Ib/acre) ${ }^{1}$ & Production (Ib) $^{{ }^{1}}$ \\
\hline China & $1,603.71$ & $19,393.90$ & $31,102,191.4$ \\
\hline United States & 289.20 & $25,431.20$ & $7,354,703.00$ \\
\hline India & 479.30 & $5,101.49$ & $2,445,144.16$ \\
\hline Spain & 83.21 & $22,464.84$ & $1,869,299.34$ \\
\hline Italy & 85.15 & $18,039.18$ & $1,536,036.18$ \\
\hline Japan & 52.67 & $21,979.86$ & $1,157,679.23$ \\
\hline Iran & 42.12 & $24,951.77$ & $1,050,968.55$ \\
\hline Turkey & 55.79 & $17,478.56$ & $975,128.862$ \\
\hline Mexico & 50.72 & $19,179.77$ & $972,797.93$ \\
\hline Germany & 38.22 & $18,807.80$ & $718,834.11$ \\
\hline${ }^{1}$ Values expressed in thousands Ib. & & & \\
\end{tabular}

Table 2. Lettuce cultivars used as differentials to identify lettuce downy mildew races in the United States according to The International Bremia Evaluation Board (IBEB). Source: https://www.worldseed.org/

\begin{tabular}{|c|c|c|c|c|c|c|c|c|c|c|c|}
\hline \multirow[t]{2}{*}{ Cultivar } & \multicolumn{11}{|c|}{ Races } \\
\hline & Bl:1aUS & Bl:1bUS & Bl:2aUS & Bl:2bUS & Bl:3US & Bl:4US & Bl:5US & Bl:6US & Bl:7US & Bl:8US & BI:9US \\
\hline Green Towers ${ }^{1}$ & + & + & + & + & + & + & + & + & + & + & + \\
\hline Dandie & + & + & + & + & + & + & + & + & + & + & + \\
\hline R4T757D & - & - & - & - & + & + & - & + & - & + & - \\
\hline UCDm14 & + & + & + & + & + & + & + & + & + & + & + \\
\hline NunDm15 & - & - & - & - & - & - & - & - & + & - & + \\
\hline CGDm16 & - & - & - & - & + & - & - & - & + & + & + \\
\hline Colorado & - & - & - & - & + & & - & - & + & + & + \\
\hline FrRsal-1 & & & & & & & & & & & - \\
\hline Argeles & & & - & - & + & & - & - & - & - & - \\
\hline Muraires & & & + & - & + & & & & - & - & + \\
\hline Silvinas & & & - & - & - & & & & - & - & - \\
\hline Bedford & & & + & + & + & & & & + & + & + \\
\hline Balesta & & & - & - & - & & & & - & - & - \\
\hline Bartoli & & & & & & & & & - & - & - \\
\hline Design & & & & & & & & & & & + \\
\hline Kibrille & & & & & & & & & & & - \\
\hline+ & - & $\begin{array}{l}\text { Confirmec } \\
\text { pathotyp }\end{array}$ & diagnostic & cores for & + & - & Suspec & scores & & & \\
\hline
\end{tabular}

${ }^{1}$ Universal susceptible cultivar. 
Table 3. Assessment of downy mildew disease severity in commercial cultivars, UF/IFAS breeding lines, and old cultivars used in Florida in the winter of 2017.

\begin{tabular}{|c|c|c|c|c|c|}
\hline Commercial Cultivars & Severity $^{1}$ & $R / S$ & UF/IFAS Lines & Severity & $R / S$ \\
\hline Hialeah & 1.4 & SR & 60162 & 1.6 & SR \\
\hline Belle Glade & 1.6 & SR & 60173 & 1.6 & SR \\
\hline Lantana & 1.6 & SR & 60158 & 1.6 & SR \\
\hline Chosen & 1.7 & SR & 1443 & 1.6 & SR \\
\hline Flagler & 1.7 & SR & 70202 & 1.6 & SR \\
\hline Manatee & 1.8 & SR & 46087 & 1.7 & SR \\
\hline Okeechobee & 1.9 & SR & C1142 & 1.8 & SR \\
\hline Homestead & 1.9 & SR & 60183 & 1.8 & $S R$ \\
\hline Cooper & 2.0 & $S R$ & 50664 & 1.8 & $S R$ \\
\hline Sawgrass & 2.1 & SR & 60174 & 1.8 & SR \\
\hline UF/IFAS Lines & Severity & $R / S$ & 60179 & 1.8 & SR \\
\hline 49019 & 1.0 & $\mathrm{R}$ & 60169 & 1.9 & SR \\
\hline 47079 & 1.0 & $\mathrm{R}$ & 45060 & 1.9 & $S R$ \\
\hline 49019 & 1.1 & $\mathrm{R}$ & 60154 & 1.9 & SR \\
\hline 48060 & 1.2 & SR & 60172 & 2.0 & SR \\
\hline 1508 & 1.2 & $S R$ & 50098 & 2.0 & SR \\
\hline 47098 & 1.2 & SR & 50011 & 2.0 & SR \\
\hline 49530 & 1.3 & SR & 60159 & 2.1 & SR \\
\hline C1139 & 1.3 & $S R$ & 60184 & 2.1 & SR \\
\hline C1143 & 1.3 & SR & 49085 & 2.2 & SR \\
\hline C1145 & 1.3 & SR & 50114 & 2.3 & SR \\
\hline 18076 & 1.3 & SR & 60157 & 2.4 & SR \\
\hline 60161 & 1.3 & SR & 49889 & 2.4 & SR \\
\hline 70096 & 1.3 & SR & 50100 & 2.4 & SR \\
\hline 60176 & 1.3 & SR & 1265 & 2.5 & S \\
\hline 60178 & 1.3 & SR & 49758 & 2.5 & $S$ \\
\hline 1502 & 1.4 & SR & 60156 & 2.5 & s \\
\hline 60163 & 1.4 & SR & 60180 & 2.7 & $S$ \\
\hline 60166 & 1.4 & SR & 60155 & 3.9 & $S$ \\
\hline 60167 & 1.4 & $S R$ & 60185 & 4.3 & S \\
\hline 43007 & 1.4 & SR & UF/IFAS Cultivars & Severity & $R / S$ \\
\hline 47083 & 1.4 & SR & Floribibb & 1.4 & SR \\
\hline 60160 & 1.4 & $S R$ & Floricrisp 1265 & 1.6 & SR \\
\hline 60168 & 1.4 & SR & Minetta & 1.7 & SR \\
\hline 49017 & 1.5 & SR & Shawnee & 1.8 & SR \\
\hline 60171 & 1.5 & $S R$ & Floricos 83 & 2.1 & SR \\
\hline
\end{tabular}

